\title{
Identifikasi Talas-Talasan Edible (Araceae) Di Semarang, Jawa Tengah
}

\author{
Khalisa Aini Sinaga, Murningsih dan Jumari \\ Laboratorium Ekologi dan Sistematik, Departemen Biologi, Fakultas Sains dan Matematika, \\ Universitas Diponegoro Jl. Prof. H. Sudharto, Tembalang, Semarang.
}

\begin{abstract}
Talas-talasan (Family Araceae) is ) is a plant known to the Indonesian people. Araceae has been cultivated and used by Indonesian people. Tuber of Family Araceae have high carbohydrate, carbohydrate composed of amylum (amylose and amylopectin). food quality is determined by ratio of amylose and amylopectin. Information about Araceae in Semarang are still limit. Indonesian people didn't know potential of the family araceae in field of food. The research objective to determine types ofedible plants from the family Araceae.The research was conducted from April to June 2016. Sampling was conducted at Jabungan, Mluweh and Susukan village, Semarang. Methods of data collection is ekploration. Identification refers to the genera of Araceae (Mayo, 1997) and characterization refers Descriptor Taro (IPGRI, 1999). Based on the results is 13 species of plants from the family Araceae. Differences among species Family Araceae character is the color and shape of the tubers, the tip of leaf blade, the edge of leaf blade, the top and bottom surface of leaf blade, leaf blade holder, and the shape of leaf blade.
\end{abstract}

Kata kunci :Identification, Morphology Character, Araceae.

\begin{abstract}
Abstrak
Talas-talasan (Famili Araceae) merupakan tanaman yang sudah dikenal masyarakat.Araceae sudah dibudidayakan serta banyak dimanfaatkan oleh masyarakat Indonesia.Umbi dari jenis Famili Araceae memiliki karbohidrat tinggi yang tersusun dari amilum (amilosa dan amilopektin). Perbandingan amilosa dan amilopektin akan menentukan kualitas pangan yang dihasilkan. Informasi mengenai Araceae di semarang masih terbatas. Masyarakat Indonesia tidak mengetahui potensi Araceae.Tujuan penelitian untuk mengetahui jenis tanaman edible dari famili Araceae.Penelitian dilaksanakan pada bulan April sampai Juni 2016. Pengambilan dilakukan di Desa Jabungan, Mluweh dan Susukan, Semarang. Metode pengumpulan data jelajah. Identifikasi mengacu pada the genera of Araceae (Mayo, 1997) dan karakterisasi mengacu pada Descriptor Taro (IPGRI,1999). Berdasarkan hasil penelitian diperoleh 13 jenis tanaman dari famili Araceae.Perbedaan karakter antar jenis Famili Araceae terlihat pada warna dan bentuk umbi, ujung helaian daun, tepi helaian daun, permukaan atas dan bawah helaian daun, dudukan helaian daun, dan bentuk helaian helaian daun.
\end{abstract}

Kata kunci : Identifikasi, Edible, Araceae.

\section{PENDAHULUAN}

Famili Araceae terdiri dari 110 marga, yang meliputi 3.200 jenis.Famili Araceae termasuk suku talas-talasan yang mencakup herba terestrial (darat),mengapung di perairan (akuatik), dan merambat pada pepohonan (epifit)(Kurniawan et al., 2013).TanamanAraceaesangat dipengaruhi oleh faktor lingkungan seperti cahaya, kelembaban yang relatif tinggi, suhu udara berkisar 25 $300^{\circ} \mathrm{C}$, pH tanah $5-7,5$ (Khoirul, 2014).
Karakteristik kunciFamili Araceae adalah perbungaan yang tersusun dalam bentuk tongkol (spadix) yang dikelilingi oleh seludang (spathe) (Boyce et al.,2010).Menurut IPGRI (1999) bentuk seludang permukaan pada Araceae ada yang berbentuk tertutup, dimiringkan, datar, terbuka terkulai, tergulung, terputar, dan tergulung memutar.

Araceae memiliki sistem parakaran yang relatif dangkal dengan daya jangkau akar 
mencapai kedalaman 40- $60 \mathrm{~cm}$ dari permukaan tanah (Muchtadi dan Sugiyono, 1992).Batang dibawah tanah membentuk umbi, umbi yang terbentuk memiliki keragaman bentuk yaitu berbentuk kerucut, mebulat, silindris, elips, halter, memanjang, datar, dan tandan (IPGRI, 1999).

Daun pada tanaman Araceae memiliki daun tunggal, berbagi atau majemuk, tersusun sebagai roset akar, tersebar pada batang atau bersilangan dalam 2 baris.Helaian daun bentuk perisai, jantung atau tombak, anak panah (Tjitrosoepomo, 1996).Menurut IPGRI (1999) bentuk tepi daun pada tanaman Araceae memiliki bentuk rata, berombak (Undulate) atau bergerigi (Sinuate).Tanaman Araceae memiliki bentuk helaian daun yang bermacam-macam yaitu bentuk terkulai, datar, mencekung atau cup, tegak keatas dan tegak kebawah.

Penelitian mengenai karakteristik Araceae di Indonesia masih terbatas, padahal Indonesia memiliki tingkat keanekaragaman Araceae yang tinggi.Kurangnya informasi mengenai manfaat Araceae menyebabkan masyarakat tidak minat dan tidak melakukan budidaya Araceae.Padahal Araceae memliki potensi pengambangan dibidang pangan sebagai diversifikasi pangan lokal dalam memenuhi kebutuhan masyarakat Indonesia terhadap kurangnya pasokan beras.Kajian mengenai karakteristik Araceae perlu dilakukan untuk mengetahui karakter yang dimiliki oleh Araceae sebagai informasi terbaru.

\section{BAHAN DAN METODE}

Penelitian dilakukan dengan pengambilan sampel tanaman Araceae di Desa Jabungan, Desa Mluweh dan Desa Susukan, Ungaran, Kabupaten Semarang, Provinsi Jawa Tengah.Penelitian ini dilakukanpada bulan April - Mei 2016. Alat yang digunakan dalam penelitian ini antara lain adalah plastik koleksi, etiket atau label, pisau, sekop, kamera, buku identifikasi tanaman, tabel pengamatan sementara, alat tulis. Bahan yang digunakan dalam penelitian ini yaitu tanaman familiAraceae yang terdapat di lokasi penelitian.

Metode penelitian dilakukan dengan metode jelajah.tanaman Araceae yang ditemukan dikoleksi meliputi organ tanaman yaitu umbi, tangkai daun, daun dan bunga. Dokumentasi, karakterisasi dan identifikasi terhadap sampel tanaman.Karakterisasi mengacu pada IPGRI (1999) dan identifikasi mengacu pada Mayo et al. (1997).Data yang diperoleh kemudian ditabulasi dan dideskripsikan.

\section{HASIL DAN PEMBAHASAN}

Berdasarkan hasil penelitian diperoleh 11 jenis tanaman dari golongan famili Araceae yang bersifat edible.Hasil identifikasi diperoleh 11 jenis tanaman tersebut dari 5 genus Araceae yaitu genus Alocasia (2 jenis), Colocasia (4 jenis), dan Xanthosoma (5 jenis).Identifikasi dilakukan mengacu pada the genera of Araceae (Mayo et al., 1997).Jenis Tanaman Araceae disajikan pada tabel 1.

Tabel 1. Jenis Tanaman Araceae di Desa Jabungan, Desa Muweh dan Desa Susukan

\begin{tabular}{llll}
\hline No & Nama lokal & Nama ilmiah & Lokasi ditemukan \\
\hline 1. & Sente hijau & Alocasia macrorrizha & Jabungan, Mluweh, Susukan \\
2. & Sente wulung & Alocasia plumbea & Jabungan, Mluweh \\
3. & Talas wulung & Colocasia sp & Jabungan \\
4. & Talas bentul & Colocasia esculenta & Jabungan \\
5. & Talas Linje & Colocasia esculenta & Jabungan \\
6. & Talas Luwak & Colocasia sp & Mluweh \\
7. & Kimpul endro & Xanthosoma sagittifolium & Jabungan, Mluweh, Susukan \\
8. & Kimpul Plecet & Xanthosoma sp & Susukan \\
9. & Kimpul Pari & Xanthosoma sp & Jabungan \\
10. & Kimpul Banyu & Xanthosoma sp & Jabungan \\
11. & Kimpul gagak & Xanthosoma sp & Mluweh \\
\hline
\end{tabular}


Araceaememiliki karakter umum yaitu tanaman herbaceous dengan arah tumbuh tegak lurus, akar serabut, memiliki umbi, helaian daun berbentuk perisai, berdaun lengkap (memiliki pelepah daun, tangkai daun, helaian daun), daun tunggal, pangkal helaian daun berlekuk, susunan tulang helaian daun menyirip, daging helaian daun seperti kertas, dan umur tanaman perennial.

Araceae memiliki karakteristik khusus yang menjadi karakter pembeda antar spesies famili araceae.karakteristik khusus disajikan pada atabel 2.

Tabel 2. Karakteristik khusus pada 11 jenis Araceae

\begin{tabular}{|c|c|c|c|c|c|c|}
\hline & Nama spesies & $\begin{array}{l}\text { helaian } \\
\text { (lamina) }\end{array}$ & mbi & perbungaan & in & $\mathrm{n}_{\text {daun }}^{\text {tangkai }}$ \\
\hline \multirow[t]{11}{*}{1.} & sente hijau & Apex-up & Elongated & 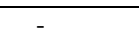 & Endulate & Non peltate \\
\hline & sente wulung & Apex-up & Cylindrical & Hooded & Endulate & Non peltate \\
\hline & talas wulung & Apex-up & Dumb-bell & - & Entire & Peltate \\
\hline & talas bentul & Apex-up & Cylindrical & - & Endulate & Peltate \\
\hline & talas linje & Apex-up & Cylindrical & - & Endulate & Peltate \\
\hline & talas luwak & Dropping & Round & - & Entire & Peltate \\
\hline & kimpul endro & Horizontal & Elongated & Hooded & Endulate & Non peltate \\
\hline & kimpul plecet & Cup-shaped & Elliptical & - & Endulate & Non peltate \\
\hline & kimpul pari & Apex-up & Elliptical & - & Endulate & Peltate \\
\hline & kimpul banyu & Horizontal & Cylindrical & - & Endulate & Peltate \\
\hline & kimpul gagak & Apex-down & Elliptical & - & Endulate & Peltate \\
\hline
\end{tabular}

Berdasarkan bentuk umbinya terdapat lima bentuk yaitu elongatedpada sente hijau (Alocasia macrorrhiza), kimpul endro (Xanthosoma sagittifolium). Cylindricalpadasente wulung (Alocasia plumbea), talas bentul (Colocasia esculenta), talas linje (Colocasia esculenta), dan kimpul banyu (Xanthosoma sp).Dumbbellpadatalas wulung (Colocasia sp).Roundyaitu talas luwak(Colocasia sp). Elliptical padakimpul pari (Xanthosoma sp), kimpul gagak (Xanthosoma sp), dan kimpul plecet(Xanthosoma sp).

Berdasarkan helaian daun terdapat 5 tipe yaitu apex-downpada kimpul gagak (Xanthosoma sp). apex-uppada sente hijau (Alocasia macrorrhiza), sente wulung (Alocasia plumbea), talas wulung (Colocasia sp), talas bentul (Colocasia esculenta), talas linje (Colocasia esculenta), dan kimpul pari (Xanthosoma sp). Droppingpadatalas luwak (Colocasia sp). Horizontalpada a, , kimpul endro (Xanthosoma sagittifolium), dan kimpul banyu(Xanthosoma sp). Cup-shaped pada 1 jenis tanaman yaitu kimpul plecet (Xanthosoma sp).Menurut IPGRI (1999) bentuk helaian apex down merupakan bentuk helaian daun yang tegak kebawah dengan tepi daun mengarah kebawah.Dropping merupakan bentuk helaian daun yang terkulai kebawah atau pada bagian tepi daun saja yg terjauh kebawah.Horizontal merupakan bentuk helaian daun yang datar berada pada lurus horizontal.Cupshaped merupakan bentuk helaian daun yang menyerupai mangkok.

Berdasarkan tepi daun terdapat dua tipe yaituentire pada genus Colocasia (1 jenis), Homalomena (1 jenis), dan schismatoglottis (1 jenis) sedangkan tepi daun endulate terdapat pada genus Alocasia (2 jenis), Colocasia (3 jenis) dan Xanthosoma (5 jenis).Tepi daun entire adalah tepi daun yang rata, tepi daun endulate adalah tepi daun yang bergelombang. Berdasarkan tipe bunga ditemukan 1 tipe yaitu hooded pada Alocasia plumbea (sente wulung), Homalomena cordata (kajar merah), Schismatoglottis sp (kajar hijau)dan Xanthosoma sagittifolium (endro), sedangkan 9 tanaman belum ditemukan adanya bunga. Menurut IPGRI (1999) hooded merupakan bentuk perbungaan dimana tongkol bunga tertutupi oleh seludang bunga.

Berdasarkan dudukan daun terdapat dua tipe yaitu nonpeltate pada sente hijau(Alocasia macrorrhiza), sente wulung(Alocasia plumbea), , kimpul endro(Xanthosoma sagittifolium), dan kimpul plecet(Xanthosoma sp). Tipe peltate pada talas wulung (Colocasia sp), talas bentul 
(Colocasia esculenta), talas linje (Colocasia esculenta), talas luwak (Colocasia sp), kimpul pari (Xanthosoma sp), kimpul banyu (Xanthosoma sp), kimpul gagak (Xanthosoma sp)

\section{KESIMPULAN}

Araceae memiliki karakter kunci yaitu perbungaan yang tersusun oleh tongkol (spadix) yang dikelilingi oleh seludang (spathe).Berdasarkan karakterisasi yang dilakukan ditemukan satu bentuk perbungaan yaitu hooded pada tanaman sente wulung, kajar merah, kajar hijau, dan kimpul endro. karakterumum pada Famili Araceae yaitu daun berbentuk perisai, pangkal daun berlekuk, daging daun seperti kertas, susunan tulang menyirip, tipe batang basah berbentuk bulat dengan arah tumbuh tegak lurus. Karakter khusus pada masing-masing 13 tanaman jenis Famili Araceae terlihat pada ujung tepi daun, permukaan atas dan bawah daun, dudukan daun, bentuk helaian daun, warna, bentuk umbi dan umur tanaman.

\section{DAFTAR PUSTAKA}

Boyce, P.C., S. Y. Wong, A. P. J. Ting, S. E. Low, K. K. Ng, I. H. Ooi. 2010. The Araceae of Borneo- The genera. Journal ofAroideana Vol.33.
IPGRI. 1999. Descriptors for Taro. International Plant Genetic Resources Institute, Rome. Italy.

Khoirul, B. 2014. Identifikasi Tanaman Famili Araceae Di Cagar Alam Tangale Kabupaten Gorontalo. Tesis. Universitas Negeri Gorontalo.

Kurniawan, A., N. P. S. Asih, Yusammi, P. C. Boyce. 2013. Studies on the Araceae of the Lesser Sunda Island I: New Distribution Record for Alocasia alba. Garden's Bulletin Singapore 65 (2): 157-162.

Mayo, S.J., Bogner, J., and Boyce P.C., 1997.The Genera Of Aaceae. Media recources Information Services Department.Royal Botanical Garden, Kew.

Muchtadi, T.R. dan Sugiono. 1992. Ilmu Pengetahuan Bahan Pangan. Departemen Pendidikan dan Kebudayaan.Direktorat Jenderal Tinggi Pusat Antar Universitas Pangan dan Gizi. Institut Pertanian Bogor, Bogor.

Tjitrosoepomo, G. 1996. Morfologi Tanaman. Universitas Gadjah Mada Press, Yogyakarta. 